\title{
Analysis of GPER1, CXCR1 and HER-2 Immuno Expression in Follicular Thyroid Lesions and their Possible Role as Diagnostic Markers
}

\author{
Nisreen A.A. Osman ${ }^{1 *}$, Maram A. M. El-Hussieny ${ }^{2}$ \\ ${ }^{1}$ Assistant professor, Pathology department, Faculty of Medicine, Minia University, Egypt \\ ${ }^{2}$ Lecturer, Pathology department, Faculty of Medicine, Minia University, Egypt
}

*Corresponding Author: Nisreen A.A. Osman, Assistant professor, Pathology department, Faculty of Medicine, Minia University, Egypt, Email: nisr20032000@yahoo.com

\begin{abstract}
Diagnosing thyroid lesions with follicular pattern is difficult in some cases, necessitating immunohistochemical diagnostic aid. High expression of GPERI, CXCRIand HER-2 was associated with metastases and poor survival in many tumors.

The aim is to determine the benefit of using these markers alone or in combination in differential diagnosis of follicular-patterned thyroid neoplasms.

A retrospective study was conducted on 104 archival paraffin blocks that obtained from pathology department between 2010 and 2016 and divided into; Nodular hyperplasia $(n=53)$, Thyroiditis $(n=13)$, follicular adenoma FTAs $(n=17)$, papillary carcinoma PTC $(n=15)$ and follicular carcinoma FTC $(n=6)$ patients who underwent thyroidectomy.

The expression of the three molecules was higher in FTC (83.3\%, 66.7\% and 50\% respectively) when compared to either FTAs $(29.4 \%, 23.5 \%$, and $5.9 \%$ respectively) or PTC $(60 \%, 46.7 \%$, and $13.3 \%$ respectively).The differences in their protein expression between non neoplastic and neoplastic thyroid lesions were statistically significant $(P<0.001)$.

Concomitant high expression of any two or all of the three molecules had stronger correlation with the occurrence of FTC, consequently; concomitant high expression should be suggested as a valuable tool in the differentiating thyroid follicular lesions and could be therapeutic targets for treatment and better outcomes.
\end{abstract}

Keywords: Immunohistochemistry; Thyroid; Follicular Lesions, GPER1; CXCR1; HER-2.

\section{INTRODUCTION}

Nodular Lesions of the thyroid gland comprise benign and malignant tumors, as well as some forms of hyperplasia [1.2].Clinically obvious nodule develops in about $5 \%$ of general population. With introduction of ultrasound, the detection of non-palpable nodules reached 20-67 $\%$ of non-palpable nodules [3].

Follicularthyroid lesions either originate from follicular cells or have follicular pattern of growth. According to the presence or absence of some features like presence of capsule, vascular and/or capsularinvasion, papillary- carcinoma type nuclei, follicular lesions are classified into: adenomatoid nodules, follicular adenomas (FA), papillarythyroid carcinoma (PTC), follicular thyroid carcinoma(FTC), well differentiated tumours of uncertain malignant potential (WDTUMP), follicular tumour of uncertain malignant potential (FT-UMP) and Hurthle cell adenoma/carcinoma [4.5]. Follicular nodular thyroid lesions have many common morphological features, with an inter-observer and intra-observer variability in diagnosis of routinely stained slides [6].

Thyroid cancer constitutes about $1 \%$ of all epithelial malignancies worldwide and is the commonest inendocrine system. It is the $5^{\text {th }}$ most common malignancy in women and is three times more common than in men [7,8].In Egypt, it represents about $1.5 \%$ of all cancers and about $30 \%$ of endocrine malignancies. Its rate among Egyptian females is $3.28 \%$ ranking as the $6^{\text {th }}$ most common malignancy $[9,10]$. This low incidence of thyroid cancer has led to little improvements in therapy and survival rates over last two decades[11].

PTC is the most common type of thyroid cancer, accounting for $80-85 \%$ of the cases followed by FTC that accounts for $10-15 \%$ [12].The prognosis is more favourable in females and most well differentiated carcinomas occur 
during reproductive age. The use of oral contraceptives, estrogen therapy and pregnancy during this period increase the risk of thyroid cancer [13]. This supports the role of female hormones especially estrogen in thyroid carcinogenesis and hypothesised the use of antiestrogen hormone therapy for multidrug resistant thyroid cancer treatment.

The $G$ protein-coupled estrogen receptor 1 (GPER1), previously known G protein receptor 30 (GPR30), is a transmembrane receptor. GPER1 mediates a rapid response to estrogensvia binding with it. Also, it regulates variable cellular physiological functions of estrogen. GPER1 activation leads to intracellular mechanisms controlling growth, proliferation, differentiation, invasion and migration $[14,15]$.

Expression ofGPER1 was detected in various tissues throughout the body[14], and it had been found to be a significant prognostic parameter in breast, endometrial and ovarian malignant tumors. Whereas, its high expression was associated with metastases and poor survival $[16,17]$.

CXCR1 is one of the 2 high affinity receptors for the CXC chemokine interleukin-8 (IL-8). It is involved in immune and inflammatory responses in many disorders. CXCR1 is mainly expressed in neutrophils and induces chemotaxis. Also, over expression of CXCR1 was related to drug-resistance, invasion, and metastasis in several solid tumors $[18,19]$.

Human epidermal growth factor receptor 2 (HER-2) is a proto-oncogene, that belongs to epidermal growth factor receptor (EGFR) family. HER-2 contributes to physiological mechanisms of cell proliferation and differentiation by intrinsic tyrosine-kinase activity. In malignant tumours, HER-2 over expression is associated with increased disease recurrence and poor prognosis $[20,21]$. The importance of HER-2 in cancer has emerged by the effectiveness of the anti-HER-2 humanized monoclonal antibody trastuzumab (Herceptin), especially when combined with chemotherapy, for the treatment of HER2-overexpressing breast cancers. Previous studies have proposed that combining CXCR1 inhibitors with HER-2 targeted therapies can play a role in better survival during the treatment of HER-2 over expressing breast cancers [22, 23]. In thyroid cancer, previous studies showed conflicting results with HER-2 positivity rates varying from $0 \%$ to $70 \%$ [24-26]. Moreover, HER-2 expression was linked to estrogen receptors expression in thyroid tumours[13].

In the setting of breast cancer; that is more common also in females, anti-estrogen hormone therapy as well as Herceptin are already well established among protocols for treatment of breast cancer. This study aims to identify a similar role in treatment of thyroid cancer by examining the expression and significance of one of oestrogen receptors (GPER1), HER-2 and their potential therapeutic target CXCR1. Also, to determine the association between their expression progression in different follicular thyroid lesions and clinicopathological characters. And to determine their role for prognosis and their expected value as targets for treatment.

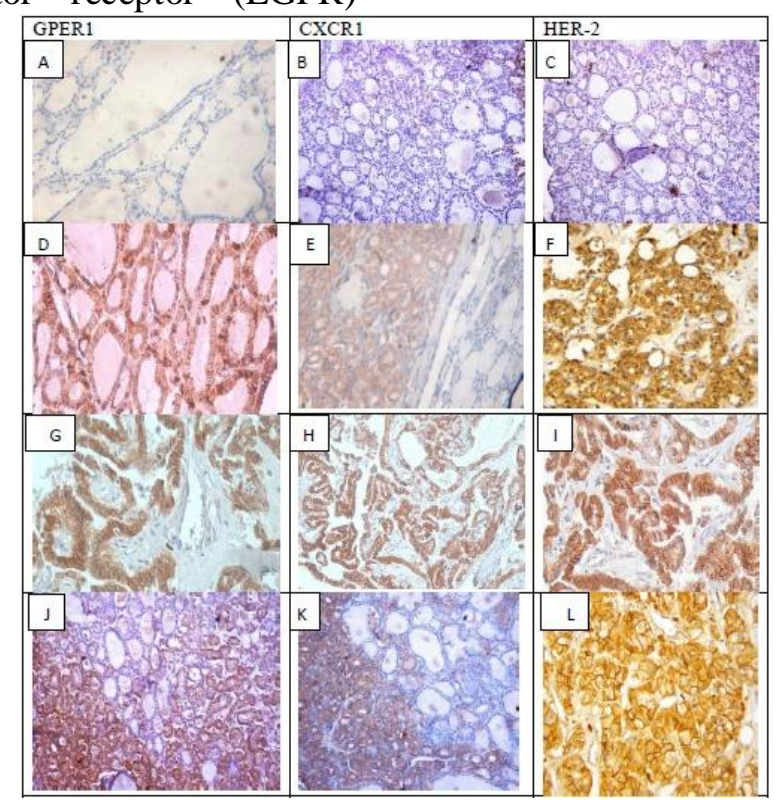

Figure1. Immunohistochemical staining for GPER1, CXCR1 and HER-2 
Columns correspond to immunostaining for GPER1, CXCR1 and HER-2, respectively. The first row exhibits negative staining of adenomatous nodules with the tested antibodies $(A-C)$; the second row shows moderate staining of FTA $(D-F)$; the third row displays strong staining of PTC $(G-I)$. and the third row displays strong staining of FTC $(J-L)$. [streptavidin biotin original magnification x200].

\section{MATERIALS AND MethodS}

\subsection{Case Selection and Tissue Sample Preparation}

In this retrospective study, all specimens that are presented with thyroid nodules at pathology lab of Minia university hospital and Minia oncology center between 2014 to 2016 were collected. There were 217 specimens divided as 98 fine needle aspiration cytology, 15 true cut biopsies and 104 surgically removed nodules. Thirty two (32) cases with fine needle aspiration were followed by excision biopsies and three (3) cases with micropapillary carcinoma were missed and diagnosed only with biopsies. This discrepancy does not occur for true cut biopsies. Patient data were retrospectively collected and summarized.

The specimens for immuno histochemistry were obtained from paraffin blocks of 104 follicular thyroid lesions divided into, Nodular hyperplasia $(n=53)$, Thyroiditis $(n=13)$, FTAs $(n=17)$, PTC $(n=15)$ and FTC $(n=6)$ patients who underwent thyroidectomy in the Department of Surgery, between January 2014 and January 2016. No other hisopathological variants of thyroid carcinoma was detected. Staging was done according to AJCC classification system [27]. Lymph node metastasis was positive in 16 of the 21 malignant cases.

Five $\mu \mathrm{m}$ sections placed on positively charged slides (CITOGLAS) were prepared. Sections were de-paraffinized with xylene, hydrated through $99.9 \%, 95 \%$, and $70 \%$ ethanol, and then treated with $3 \%$ hydrogen peroxide for 30 minutes to inactivate endogenous peroxides, washed in phosphate-buffered saline (PBS) solution. For antigen retrieval, sections were treated for 20 minutes in $0.01 \mathrm{M}$ citrate buffer (pH 6.0)by microwave, and then allow cooling.

After rinse in PBS, primary antibodies were incubated overnight in a humidity chamber using GPER1 antibody (rabbit polyclonal antibody; 1:100 dilution, ab39742; Abcam, USA), anti-CXCR1 antibody (rabbit polyclonal antibody; 1:100 dilution, ab150548; Abcam, USA) and c-erbB-2/HER-2antibody (Monoclonal mouse antibody clone e2-4001 +
3B5, Lab Vision Laboratories, Ready to use). Then slides were washed with PBS before applying the biotinylated secondary antibody (Lab Vision Laboratories) for 30 minutes. Sections washed in PBS, incubated with the streptavidin-biotin complex reagent (Lab Vision Laboratories) for 30 minutes.

A brown color was developed with 3, 3diaminobenzidinetetra hydrochloride (DAB, Lab Vision Laboratories) for 5 minutes, then washed in distilled water, counterstained with Mayer's haematoxylin, dehydrated, cleared in xylene, mounted and covered slipped. Each staining batch included positive and negative control sections.

\subsection{Scoring of Immunostaining}

A semiquantitative assessment of immunohistochemical (IHC) scoring for GPER1 and CXCR1 was performed by two observers blinded to the diagnosis. The IHC score was assigned based on staining intensity and percentage of positive cells. The intensity score was assigned as 0 (no staining), 1 (weak staining), 2 (moderate staining), and 3 (strong staining). The proportion score was assigned as 0 ( $<5 \%$ positive cells), 1 ( $6-25 \%$ positive cells), 2 (26-50\% positive cells), 3 (51-75\% positive cells), and 4 (> 75\% positive cells). Multiplication of the intensity and percentage scores gave rise to the final staining score: 0 (negative), $+(1-4),++(5-8)$, and +++ (9-12). For statistical analysis, a final staining score of negative or + or ++ without gene amplification was combined into the low expression group, and a final staining score of ++ with gene amplification or +++ was combined into the high expression group [28].

HER-2 expression was evaluated using immunohistochemistry (IHC) and scored according to the updated ASCO-CAP system [29]. Fluorescent in situ hybridization (FISH) was done if HER-2 expression was classed as +2 in IHC. HER-2 was considered to be over expressed if it was classed as +3 by IHC or if showed gene amplification in FISH test. Fluorescent in situ hybridization was performed 
using Vysis DNA probe kit (PathVysion, USA). Gene amplification was recorded when the ratio HER-2/centromeric probe for chromosome 17 (CEP17) signal was $\geq 2.0$. For statistical analysis, a final staining score of negative or +1 was combined into the low expression group, and a final staining score of +2 or +3 was combined into the high expression group.

\subsection{Statistical Analysis}

Statistical analysis was performed using SPSS 18.0(SPSS Inc., Chicago, IL, USA) statistical software. Chi-square test was used to determine the significance of any differences between the IHC scores for groups of tissue specimens. A Pvalue $<0.05$ was considered statistically significant.

\section{Results}

\subsection{Clinicopathological Data of Patients}

The examined cases were 82 females and 22 males. The mean age of cases was $40.17 \pm 1.47$ years with a median of 40 years (range 14-85 years).

Table1. Association between GPER1, CXCR1 and HER-2 protein expression and clinicopathological parameters in cases studied (104 cases)

\begin{tabular}{|c|c|c|c|c|c|c|}
\hline Clinicopathological data & $\begin{array}{c}\text { Low } \\
\text { GPER1 } \\
(\%) \\
\end{array}$ & $\begin{array}{c}\text { High } \\
\text { GPER1 } \\
(\%) \\
\end{array}$ & $\begin{array}{c}\text { Low } \\
\text { CXCR1 } \\
(\%)\end{array}$ & $\begin{array}{c}\text { High } \\
\text { CXCR1 } \\
(\%)\end{array}$ & $\begin{array}{c}\text { Low } \\
\text { HER- } \\
2(\%)\end{array}$ & $\begin{array}{c}\text { High } \\
\text { HER- } \\
2(\%) \\
\end{array}$ \\
\hline Age & & & & & & \\
\hline$<40 y s(n=50)$ & $44(88)$ & $6(12)$ & $46(92)$ & $4(8)$ & $50(100)$ & $0(0)$ \\
\hline$\geq 40 y s(n=54)$ & $39(72.2)$ & $15(27.7)$ & $38(70.37)$ & $16(29.63)$ & $48(88.8)$ & $6(11.2)$ \\
\hline$P$ value & \multicolumn{2}{|l|}{0.045} & \multicolumn{2}{|l|}{0.005} & \multicolumn{2}{|l|}{0.015} \\
\hline \multicolumn{7}{|l|}{ Gender } \\
\hline Males (n=22) & $17(77.27)$ & $5(22.73)$ & $17(77.27)$ & $5(22.73)$ & $18(82)$ & $4(18)$ \\
\hline Females $(n=82)$ & $66(80.48)$ & $16(19.52)$ & $67(81.70)$ & $15(18.30)$ & $80(97.6)$ & $2(2.4)$ \\
\hline$P$ value & \multicolumn{2}{|l|}{0.739} & \multicolumn{2}{|l|}{0.639} & \multicolumn{2}{|l|}{0.005} \\
\hline \multicolumn{7}{|l|}{ Diagnosis } \\
\hline Nodular hyperplasi & $53(100)$ & $0(0)$ & $53(100)$ & $0(0)$ & $53(100)$ & $0(0)$ \\
\hline Thyroiditis (n=13) & $11(84.61)$ & $2(15.39)$ & $8(61.53)$ & $5(38.47)$ & $13(100)$ & $0(0)$ \\
\hline FAs $(n=17)$ & $12(70.58)$ & $5(29.42)$ & 13(76.47) & $4(23.53)$ & $16(94.1)$ & $1(5.9)$ \\
\hline PTC $(n=15)$ & $6(40)$ & $9(60)$ & $8(53.33)$ & $7(46.76)$ & $13(86.7)$ & $2(13.3)$ \\
\hline FTC $(n=6)$ & $1(16.66)$ & $5(83.33)$ & $2(33.33)$ & $4(66.66)$ & $3(50)$ & $3(50)$ \\
\hline$P$ value & \multicolumn{2}{|l|}{0.000} & \multicolumn{2}{|l|}{0.000} & \multicolumn{2}{|l|}{0.000} \\
\hline \multirow{4}{*}{$\begin{array}{l}\text { Size } \\
\text { FAs }(\mathrm{n}=17) \\
<2 \mathrm{~cm}(\mathrm{n}=5) \\
2-4 \mathrm{~cm}(\mathrm{n}=6) \\
>4 \mathrm{~cm}(\mathrm{n}=6)\end{array}$} & & & & & & \\
\hline & $3(60)$ & $2(40)$ & $4(80)$ & $1(20)$ & $5(100)$ & $0(0)$ \\
\hline & $4(66.66)$ & $2(33.33)$ & $4(66.66)$ & $2(33.33)$ & $5(83.3)$ & $1(16.7)$ \\
\hline & $5(83.33)$ & $1(16.66)$ & $5(83.33)$ & $1(16.66)$ & $6(100)$ & $0(0)$ \\
\hline$P$ value & \multicolumn{2}{|l|}{0.676} & \multicolumn{2}{|l|}{0.774} & \multicolumn{2}{|l|}{0.378} \\
\hline PTC $(n=15)$ & & & & & & \\
\hline$<2 \mathrm{~cm}(\mathrm{n}=3)$ & $3(\mathbf{1 0 0})$ & $0(0)$ & $3(100)$ & $0(0)$ & $3(100)$ & $0(0)$ \\
\hline $2-4 \mathrm{~cm}(\mathrm{n}=11)$ & $2(18.18)$ & $9(81.81)$ & $4(36.36)$ & 7 (63.63) & $9(81.8)$ & $2(18.2)$ \\
\hline$>4 \mathrm{~cm}(\mathrm{n}=1$ & $1(100)$ & $0(0)$ & $1(100)$ & $0(0)$ & $1(100)$ & $0(0)$ \\
\hline$P$ value & \multicolumn{2}{|l|}{0.017} & \multicolumn{2}{|l|}{0.092} & \multicolumn{2}{|l|}{0.657} \\
\hline
\end{tabular}

3.2. Expression of GPER1, CXCR1 and HER2 in Different Nodular Thyroid Tissues and their Association with Clinico Pathological Features

GPER1, CXCR1 and HER-2 protein expressions were detected in the cytoplasm and cell membrane. Their expression levels were significantly higher with advanced age $\geq 40$ years $(\mathrm{p}=0.045,0.005$ and 0.015 respectively), and with female gender only with HER-2 expression $(\mathrm{p}=0.005)$. The expression was low in all cases of nodular hyperplasia and most cases of thyroiditis. While, the expression was increased in thyroid carcinomas compared to FA for all three molecules as shown in Table 1. No significant association was detected between protein expression of the three molecules with size in FA. The same previous association was significant only with GPER1 in PTC $(\mathrm{p}=0.017)$ and only for CXCR1 in FC ( $\mathrm{p}=0.050)$.Lymph node metastasis and advanced tumor stage were significantly associated with GPER 1 and CXCR1 expression. Whereas, Her-2 expression was significantly higher with only tumor stage $(\mathrm{p}=0.023)$ 
Analysis of GPER1, CXCR1 and HER-2 Immuno Expression in Follicular Thyroid Lesions and their Possible Role as Diagnostic Markers

\begin{tabular}{|c|c|c|c|c|c|c|}
\hline $\begin{array}{l}\text { FTC }(n=6) \\
<2 \mathrm{~cm}(\mathrm{n}=1) \\
2-4 \mathrm{~cm}(\mathrm{n}=2) \\
>4 \mathrm{~cm}(\mathrm{n}=3)\end{array}$ & $\begin{array}{l}0(0) \\
1(50) \\
0(0)\end{array}$ & $\begin{array}{l}1(100) \\
1(50) \\
3(100)\end{array}$ & $\begin{array}{l}0(0) \\
2(100) \\
0(0)\end{array}$ & $\begin{array}{l}1(100) \\
0(0) \\
3(100)\end{array}$ & $\begin{array}{l}0(0) \\
2(100) \\
1(33.3)\end{array}$ & $\begin{array}{l}1(100) \\
0(0) \\
2(66.7)\end{array}$ \\
\hline$P$ value & \multicolumn{2}{|l|}{0.301} & \multicolumn{2}{|l|}{0.050} & \multicolumn{2}{|l|}{0.189} \\
\hline $\begin{array}{l}\text { LN metastasis in malignant } \\
\text { cases } \\
\text { Positive }(n=16) \\
\text { Negative }(n=5)\end{array}$ & $\begin{array}{l}2(12.5) \\
5(100)\end{array}$ & $\begin{array}{l}14(87.5) \\
0(0)\end{array}$ & $\begin{array}{l}5(31.25) \\
5(100) \\
\end{array}$ & $\begin{array}{l}11(68.75) \\
0(0)\end{array}$ & $\begin{array}{l}11(100) \\
5(100)\end{array}$ & $\begin{array}{l}5(0) \\
0(0)\end{array}$ \\
\hline$P$ value & \multicolumn{2}{|l|}{0.000} & \multicolumn{2}{|l|}{0.007} & \multicolumn{2}{|l|}{0.152} \\
\hline $\begin{array}{l}\begin{array}{l}\text { Stage in malignant cases } \\
(\mathbf{n}=21)\end{array} \\
\text { I }(\mathbf{n}=\mathbf{6}) \\
\text { II }(\mathbf{n}=9) \\
\text { III }(\mathbf{n}=5) \\
\text { IV }(\mathbf{n = 1})\end{array}$ & $\begin{array}{l}5(83.33) \\
2(22.22) \\
0(0) \\
0(0)\end{array}$ & $\begin{array}{l}1(16.66) \\
7(77.77) \\
5(100) \\
1(100)\end{array}$ & $\begin{array}{l}5(83.33) \\
4(44.44) \\
1(20) \\
0(0)\end{array}$ & $\begin{array}{l}1(16.66) \\
5(55.55) \\
4(80) \\
1(100)\end{array}$ & $\begin{array}{l}6(100) \\
8(88.9) \\
2(40) \\
0(0)\end{array}$ & $\begin{array}{l}0(0) \\
1(11.1) \\
3(60) \\
1(100)\end{array}$ \\
\hline$P$ value & \multicolumn{2}{|l|}{0.017} & \multicolumn{2}{|l|}{0.0136} & \multicolumn{2}{|l|}{0.023} \\
\hline
\end{tabular}

Chi-square test was used, $p<0.05$ was considered statistically significant

The concomitant low expression of the three molecules was noted in $76.9 \%$ in all thyroid cases studied, in $70.6 \%$ of FA and in $33.3 \%$ of thyroid carcinomas (Table 4). While only one case $(5.9 \%)$ of FA and 5 cases $(23.8 \%)$ of thyroid carcinomas showed concomitant high expression and they were stratified as 2 cases of PTC and 3 cases of FC.

Table4. Correlation of concomitant expression of GPERI, CXCRI and HER-2 in all cases (104 cases), follicular adenoma (17cases) and malignant tumors (21 cases)

\begin{tabular}{|c|c|c|c|c|c|c|}
\hline Concomitant expression & $\begin{array}{l}\text { All cases } \\
(\text { no, } \%)\end{array}$ & $\begin{array}{c}\mathbf{P} \\
\text { value }\end{array}$ & $\begin{array}{c}\text { Follicular } \\
\text { Adenoma (no, \%) }\end{array}$ & $\begin{array}{c}P \\
\text { value }\end{array}$ & $\begin{array}{c}\text { Malignant } \\
\text { tumors }(\text { no, \%) }\end{array}$ & $\begin{array}{c}\mathbf{P} \\
\text { value }\end{array}$ \\
\hline $\begin{array}{l}\text { GPER1/CXCR1 } \\
\text { Both low } \\
\text { Both high } \\
\text { One of them high }\end{array}$ & $\begin{array}{l}80(76.9) \\
17(16.3) \\
7(1.8)\end{array}$ & 0.000 & $\begin{array}{l}12(70.6) \\
4(23.5) \\
1(5.9)\end{array}$ & 0.000 & $\begin{array}{l}7(33.3) \\
11(52.4) \\
3(14.3)\end{array}$ & 0.001 \\
\hline $\begin{array}{l}\text { GPER1/HER-2 } \\
\text { Both low } \\
\text { Both high } \\
\text { One of them high }\end{array}$ & $\begin{array}{l}83(79.8) \\
6(5.8) \\
15(14.4) \\
\end{array}$ & 0.000 & $\begin{array}{l}12(70.6) \\
1(5.9) \\
4(23.5)\end{array}$ & 0.110 & $\begin{array}{l}7(33.3) \\
5(23.8) \\
9(42.9)\end{array}$ & 0.070 \\
\hline $\begin{array}{l}\text { CXCR1/HER-2 } \\
\text { Both low } \\
\text { Both high } \\
\text { One of them high } \\
\end{array}$ & $\begin{array}{l}84(80.7) \\
6(5.8) \\
14(13.5) \\
\end{array}$ & 0.000 & $\begin{array}{l}13(76.5) \\
1(5.9) \\
3(17.6) \\
\end{array}$ & 0.063 & $\begin{array}{l}10(47.6) \\
5(23.8) \\
6(28.6)\end{array}$ & 0.015 \\
\hline $\begin{array}{l}\text { GPER1/CXCR1/HER-2 } \\
\text { All low } \\
\text { All high } \\
\text { Different expressions }\end{array}$ & $\begin{array}{c}80(76.9) \\
6(5.8) \\
18(17.3)\end{array}$ & 0.000 & $\begin{array}{l}12(70.6) \\
1(5.9) \\
4(23.5)\end{array}$ & 0.000 & $\begin{array}{l}7(33.3) \\
5(23.8) \\
9(42.9)\end{array}$ & 0.001 \\
\hline
\end{tabular}

Chi-square test was used, $p<0.05$ was considered statistically significant

3.3. Correlation of GPER1, CXCR1 and

HER-2 Protein Expression with One

Another in Different Nodular Thyroid Tissues

As shown in Table 2, the correlation of the studied molecules was highly significant in all

Table2. Correlation between GPER1, CXCR1 and HER-2 protein expression in all thyroid lesions studied (104 cases)

\begin{tabular}{|l|l|l|l|l|l|}
\hline \multicolumn{2}{|c|}{} & GPER1 & CXCR1 & HER-2 \\
\hline Spearman's rho & GPER1 & Correlation Coefficient & 1.000 & $.788^{* * *}$ & $.492^{* *}$ \\
\cline { 3 - 6 } & & Sig. (2-tailed) &. & .000 & .000 \\
\cline { 2 - 6 } & $\mathrm{N}$ & 104 & 104 & 104 \\
\cline { 2 - 6 } & \multirow{2}{*}{ CXCR1 } & Correlation Coefficient & $.788^{* *}$ & 1.000 & $.507^{* * *}$ \\
\cline { 3 - 6 } & & Sig. (2-tailed) & .000 &. & .000 \\
\hline
\end{tabular}

cases studied (104 cases). On studying this correlation in malignant thyroid tumors (Table 3 ), a significant correlation was noted between GPER1 and CXCR1. HER-2 expression was significant only with CXCR1 $(\mathrm{p}=0.013)$ and not with GPER1 ( $\mathrm{p}=0.76)$. 
Analysis of GPER1, CXCR1 and HER-2 Immuno Expression in Follicular Thyroid Lesions and their Possible Role as Diagnostic Markers

\begin{tabular}{|l|l|l|l|l|l|}
\hline & $\mathrm{N}$ & 104 & 104 & 104 \\
\cline { 2 - 6 } & \multirow{3}{*}{ HER-2 } & Correlation Coefficient & $.492^{* *}$ & $.507^{* *}$ & 1.000 \\
\cline { 2 - 6 } & Sig. (2-tailed) & .000 & .000 &. \\
\cline { 2 - 6 } & $\mathrm{N}$ & 104 & 104 & 104 \\
\hline
\end{tabular}

**. Correlation was measured by Chi-square test and is significant at the 0.01 level (2-tailed)

Table3. Correlation between GPER1, CXCR1 and HER-2 protein expression in all thyroid tumors studied (21 cases)

\begin{tabular}{|c|c|c|c|c|c|}
\hline \multirow{2}{*}{\begin{tabular}{|l} 
Spearman's rho \\
\end{tabular}} & & & GPER1 & CXCR1 & HER-2 \\
\hline & \multirow[t]{3}{*}{ GPER1 } & Correlation Coefficient & 1.000 & $.742^{* *}$ & .395 \\
\hline & & Sig. (2-tailed) & . & .000 & .076 \\
\hline & & $\mathrm{N}$ & 21 & 21 & 21 \\
\hline & \multirow[t]{3}{*}{ CXCR1 } & Correlation Coefficient & $.742^{* * *}$ & 1.000 & $.533^{*}$ \\
\hline & & Sig. (2-tailed) & .000 & & .013 \\
\hline & & $\mathrm{N}$ & 21 & 21 & 21 \\
\hline & \multirow[t]{3}{*}{ HER-2 } & Correlation Coefficient & .395 & $.533^{*}$ & 1.000 \\
\hline & & Sig. (2-tailed) & .076 & .013 & \\
\hline & & $\mathrm{N}$ & 21 & 21 & 21 \\
\hline
\end{tabular}

Correlation was measured by Chi-square test.

**. Correlation is significant at the 0.01 level (2-tailed).

*. Correlation is significant at the 0.05 level (2-tailed).

\section{DISCUSSION}

Many studies suggested estrogen role in thyroid carcinogenesis [30]. GPER1 is a new member of the estrogen receptor family that mediates response to estrogen through activation of epidermal growth factor receptor (EGFR). This leads to production of several downstream signaling molecules that are associated with cancer cell proliferation, invasion, metastasis and resistance to therapy [31]. CXCR1 was found to be involved in EGFR activation through interaction with GPER1 especially in estrogen negative cancer [32]. It was reported that GPER1 protein expression was higher in endometrial carcinoma, ovarian carcinomas and lung tumors, when compared with their normal or benign tissues [33-35].On the contrary; GPER1was positive in all samples of normal breast, while in carcinoma cases only $42 \%$ were positive [36].

In the present study, upregulation of GPER1, CXCR1 and HER-2 expression was found from FA to PTC and FC cases. The expression of the three molecules was higher in FC $(83.3 \%$, $66.7 \%, 50 \%$ respectively) when compared to either FA $(29.4 \%, 23.5 \%, 5.9 \%$ respectively) or PC $(60 \%, 46.7 \%, 13.3 \%$ respectively). Similar results were observed in previous studies [1415 ; 26].However, concomitant expression of GPER1, CXCR1 and HER-2 was not investigated in previous studies. In the present study, the differences in GPER1, CXCR1, and HER-2 protein expression between non neoplastic thyroid tissues and thyroid tumors were statistically significant $(\mathrm{P}<0.001)$. On the contrary,CXCR1 expressionwas lower in thyroid normal cells compared to transformed cells[37].

When the correlation of GPER1, CXCR1and HER-2 protein expression with clinicopathological parameters was assessed, it was found that GPER and CXCR1 protein expression were associated with age, histopathological diagnosis, nodal metastasis and TNM stage. Previous study found significant correlation between both protein expressions and lymph node metastasis in PC [28].Another study on follicular adenomas and carcinomas, detected positive correlation only with histopathological diagnosis and both proteins [15].

HER-2 protein expression was associated only with age, gender, histopathological diagnosis and TNM stage. But, neither of molecules studies was associated with the size. These results suggested that GPER1, EGFR and HER2 may play an important role in invasion and metastasis of malignant thyroid tumors.

Additionally, our study, for the first time, demonstrated a significantly positive correlation between GPER1, CXCR1 and HER-2 expression in different thyroid lesions. These findings could be supported by the high protein expression of the three molecules especially in neoplastic thyroid tissues in previous studies $[15,26]$. However, it is necessary to further elucidate the molecular mechanisms underlying these correlations. 
To our knowledge, this is the first study that demonstrated a positive correlation of GPER1, CXCR1 and HER-2 expression in FA, PTC and FC of the thyroid. High expression of GPER1, CXCR1 and HER-2 was associated with tumor stage. So studying the protein expression level of the three molecules can predict the tumor stage and subsequent response to targeted therapy and patients' prognosis. Future studies on larger number of cases will be necessary to determine the utility of these molecules as molecular markers for therapy in thyroid tumors.

Reparixin, a clinical CXCR1/2 inhibitor. When it was combined with 5-Fluorouracil, it prevented malignant gastric cells proliferation, survival and migration both in vitro and in vivo [38]. Recent studies had provided evidence that using Reparixin affects various phenotypes of thyroid cancer cells. Also it did not exert any effect on non-neoplastic thyroid cell growth and survival even at the high concentrations [37;39].So, detecting CXCR1 in thyroid carcinoma is important to select those who could be targets for Reparixin.

HER-2 expression have been previously reported in thyroid cancer with controversial results. Either due to variation in number of cases, different methodology or variable scoring criteria (40-42). In the present study; the updated ASCO-CAP system was used for assessment of HER-2 expression. High expression of HER-2 was not detected in non neoplastic thyroid tissue but was obvious in $5.9 \%$ FA, $13.3 \%$ PTC and in 50\% FC. A previous study has detected high expression of HER-2 protein in $44 \%$ of FC and in $18 \%$ of PTC with no expression in normal thyroid tissue (26). As HER-2 expression was more evident in metastatic thyroid carcinomas. Therefore, They suggest a role of HER-2 expression towards worse prognosis and eligibility for targeted therapy, such as trastuzumab especially in iodine refractory cancers (26). Also, HER-2 expression was reported to be associated with disease recurrence $(13 ; 40)$. On the contrary, others reported no significant variation in HER2 expression in benign or malignant thyroid tumors $(41 ; 42)$. On the other hand, Low rate of HER-2 over expression was reportedin $6.9 \%$ of PTC and not detected in FC cases (43).

The occurrence of cytoplasmic expression of HER-2 with membranous expression was considered non significant and should be ignored because trastuzumab only target membranous HER-2 (26). In colon cancer; cytoplasmic HER-2 was associated with survival and prognosis. Whereas, Lapatinib that targets cytoplasmic HER-2 can be used for treatment(44). Several mechanisms were suggested to explain the cytoplasmic expression of HER-2. One of them is by binding to 155 that presents in the mitochondria leading to instability of the HER-2 protein and its mRNA. Also when the incubation time is more than 30 minutes; the cytoplasmic stain appears. Another theory is due to upregulation of promoterbinding proteins leading to increase in HER-2 production (45). Moreover, cytoplasmic expression of HER-2 was not associated with gene amplification (46).

On molecular basis, HER-2 expression was detected in $38.5 \%$ of familial PTC and restricted to less than $10 \%$ of tumor cells. On comparing IHC with FISH, inconsistent results were obtained (47). In another series, No DNA amplification of HER-2 was detected in either PTC or FC. They found that cytoplasmic immunoreactivity of HER-2 was correlated with tumor differentiation (48).

Due to contradictory results between many studies, HER-2 expression profile still needs further evaluation regarding its role in prognosis of thyroid tumors.

\section{CONCLUSION}

The rates of GPER1, CXCR1 and HER-2 high expression were significantly higher in FTC than in FTA. However, their expression should not be alone suggested as a diagnostic marker for discriminating between FTC and FTA diagnosis. Concomitant high expression of any two or all of the three molecules had stronger correlation with the occurrence of FTC than did each alone. Consequently, concomitant high expression of GPER1, CXCR1 and HER-2 should be suggested as a valuable tool in the differential diagnosis between FTC and FTA.

\section{REFERENCES}

[1] Carter W.B., Tourtelot J.B., Savell J.G. et al., New treatments and shifting paradigms in differentiated thyroid cancer management, Cancer Control.18(2),(2011). Pp. 96-103.

[2] Dunđerović D., Lipkovski J.M., Boričic I., Soldatović I., Božic V., Cvejić D. and Tatić S., Defining the value of CD56, CK19, Galectin 3 and HBME-1 in diagnosis of follicular cell derived lesions of thyroid with systematic review of literature, Diagnostic Pathology. 10, p.196, (2015). 
[3] Gharib H., Papini E., Thyroid nodules: clinical importance, assessment, and a Treatment, Endocrinol.Metab. Clin., North Am.36(3), pp.707-35, (2007).

[4] Liu Z., Zhou G., Nakamura M., Koike E., Li Y., Ozaki T., et al., Encapsulated follicular thyroid tumor with equivocal nuclear changes, so-called well-differentiated tumor of uncertain malignant potential: a morphological, immunohistochemical, and molecular appraisal, Cancer Sci.102(1), pp. 288-94,(2011).

[5] Mete O., Asa S.L., Pitfalls in the diagnosis of follicular epithelial proliferations of the thyroid, Adv. Anat.Pathol. 19(6), pp.363-73, (2012).

[6] Cibas E.S., Baloch Z.W., Fellegara G., LiVolsi V.A., Raab S.S., Rosai J., et al., A prospective assessment defining the limitations of thyroid nodule pathologic evaluation, Ann. Intern. Med.159 (5), pp. 325-32, (2013).

[7] Pelizzo M.R., Dobrinja C., Casal-Ide E., et al., The role of BRAF(V600E) mutation as poor prognostic factor for the outcome of patients with intrathyroid papillary thyroid carcinoma, Biomed.Pharmacother. 68, pp.413-7, (2014).

[8] Siegel R., Miller K. and Jemal A., Cancer Statistics, 2016. Ca. Cancer J. Clin.66, pp.730,(2016).

[9] Ibrahim A., Khaled H., Mikhail N., Baraka H., and Kamel H., Cancer Incidence in Egypt: Results of the National Population-Based Cancer Registry Program, Journal of Cancer Epidemiology. Volume 2014, 18 pages, (2014).

[10] Ahmed R. and Aboelnaga E., Thyroid Cancer in Egypt: Histopathological Criteria,Correlation With Survival and Oestrogen Receptor Protein Expression, Pathol. Oncol. Res.21, pp.793-802, (2015).

[11] Sherman S. Thyroid carcinoma. Lancet.361, pp. 501-512, (2003).

[12] Chen A.Y., Jemal A. and Ward E.M., Increasing incidence of differentiated thyroid cancer in the United States, 1988-2005, Cancer. 115, pp. 3801-3807, (2009).

[13] Kavanagh D.O., McIlroy M., Myers E., Bane F., Crotty T.B. McDermott E., Hill A.D., Young L.S., The role of oestrogen receptor $\alpha$ in human thyroid cancer: Contributions from coregulatory proteins and the tyrosinekinase receptor HER2, Endocr. Relat. Cancer. 17,pp. 255-264, (2010).

[14] Prossnitz E.R., Barton M., The G-proteincoupled estrogen receptor GPER in health and disease, Nat. Rev. Endocrinol.7, pp. 715-726, (2011).

[15] Zhao L., Zhu X.Y., Jiang R., Xu M., Wang N., Chen G.G., Liu Z.M., Role of GPER1, EGFR and CXCR1 in differentiating between malignant follicular thyroid carcinoma and benign follicular thyroid adenoma, Int. J.Clin. Exp.Pathol. 8(9), pp. 11236-11247,(2015).

[16] Smith H.O., Arias P.H., Kuo D.Y., Howard T., Qualls C.R., Lee S.J., Verschraegen C.F., Hathaway H.J., Joste N.E., Prossnitz E.R., GPR30 predicts poor survival for ovarian cancer, Gynecol.Oncol. 114, pp. 465-471, (2009).

[17] Samartzis E.P., Noske A., Meisel A., Varga Z., Fink D., et al., The G Protein-Coupled Estrogen Receptor (GPER) Is Expressed in Two Different Subcellular Localizations Reflecting Distinct Tumor Properties in Breast Cancer,PLoS ONE. 9(1): e83296 (2014).

[18] Maxwell P.J., Gallagher R., Seaton A., Wilson C., Scullin P., Pettigrew J., Stratford I.J., Williams K.J., Johnston P.G. and Waugh D.J.J., HIF-1 and NF-jB-mediated upregulation of CXCR1 and CXCR2 expression promotes cell survival in hypoxic prostate cancer cells, Oncogene. 26,pp. 7333-7345, (2007).

[19] Waugh D.J., Wilson C., The interleukin-8 pathway in cancer,Clin. Cancer Res. 14, pp.6735-6741, (2008).

[20] Ha S., Lee Y., Shin S., Kim H., Kim S., Namkoong H., Kim H., Jung S., Lee Y., Chung Y., Jung S., and Kim J.,Oncoprotein HCCR-1 expression in breast cancer is well correlated with known breast cancer prognostic factors including the HER2 overexpression, p53 mutation, and ER/PR status, BMC Cancer. 9, pp. 51-56,(2009).

[21] Lae' M., Couturier J., Oudard S., Radvanyi F., Beuzeboc P., and Vieillefond A., Assessing HER2 gene amplification as a potential target for therapy in invasive urothelial bladder cancer with a standardized methodology: results in 1005 patients, Annals of Oncology. 21, pp. 815-819, (2010).

[22] Aceto N., Duss S., MacDonald G., Meyer D.S., Roloff T.C., Hynes N.E. and Bentires-Alj M., Co-expression of HER2 and HER3 receptor tyrosine kinases enhances invasion of breast cells via stimulation of interleukin- 8 autocrine secretion, Breast Cancer Research. 14:R131, (2012).

[23] Singh C., De Vera M., Campbell C.L., The effect of prospective monitoring and early physiotherapy intervention on arm morbidity following surgery for breast cancer: a pilot study, Physiother. Can. 65(2), pp.183-91, (2013).

[24] Qin C.,Cau W., Zhang Y.,Mghanga F.P., Lan X., Gao Z., An R., Correlation of clinicpathological features and expression of molecular markers with prognosis after 131I treatment of differentiated thyroid carcinoma, Clin. Nucl. Med. 37, p 40-46, (2012). 
[25] Sugishita Y.,Kammori M., Yamada O., Poon S.S., Kobayashi M., Onoda N., Yamazaki K.,Fukumori T.,Yoshikawa K.,Onose H., et al., Amplification of the human epidermal growth factor receptor 2 gene indifferentiated thyroid cancer correlates with telomere shortening, Int. J. Oncol. 42, pp.1589-1596, (2013).

[26] Ruggeri R.M., Campennì A., Giuffrè G., Giovanella L., Siracusa M., Simone A., BrancaG., Scarfì R., Trimarchi F., Ieni A., Tuccari G., HER2 Analysis in Sporadic Thyroid Cancer of Follicular Cell Origin, Int. J. Mol. Sci. 6;17(12), (2016).

[27] Lang B.H., Lo C.Y., Chan W.F., Lam K.Y. and Wan K.Y., Staging systems for papillary thyroid carcinoma: a review and comparison, Ann. Surg. 245, p. 366-378, (2007).

[28] Tang C., Yang L., Wang N., Li L., Xu M., Chen G.G., Liu Z.M.. High expression of GPER1, EGFR and CXCR1 is associated with lymph node metastasis in papillary thyroid carcinoma. Int. J.Clin. Exp. Pathol. 7(6), pp. 3213-3223, (2014).

[29] Rakha E.A., Starczynski J., Lee A.H., Ellis I.O., The updated ASCO/CAP guideline recommendations for HER2 testing in the management of invasive breast cancer: A critical review of their implications for routine practice, Histopathology. 64, pp. 609615(2014).

[30] Zeng Q., Chen G.G., Vlantis A.C., Tse G.M. and van Hasselt C.A., The contributions of oestrogen receptor is forms to the development of papillary and anaplastic thyroid carcinomas, Journal of Pathology. 214, pp. 425-433,(2008).

[31] Lappano R., Marco P.D., De Francesco E.M., Chimento A., Pezzi V., Maggiolini M., Crosstalk between GPER and growth factor signaling, J. Steroid Biochem. Mol. Biol. 137, pp. 50-56, (2013).

[32] Jiang Q.F., Wu T.T., Yang J.Y., Dong C.R., Wang N., Liu X.H., Liu Z.M., 17 $\beta$-estradiol promotes the invasion and migration of nuclear estrogen receptor-negative breast cancer cells through cross-talk between GPER1 and CXCR1, J. Steroid Biochem. Mol. Biol. 138,pp.314-324,(2013).

[33] He Y.Y., Cai B., Yang Y. X., Liu X. L., and Wan X. P., "Estrogenic G protein-coupled receptor 30 signaling is involved in regulation of endometrial carcinoma by promoting proliferation, invasion potential, and interleukin-6 secretion via the MEK/ERK mitogen-activated protein kinase pathway," Cancer Science. 100 (6), pp.1051-1061, (2009).

[34] LiuH.-D., YanY., Cao X.-F. et al., "The expression of a novelestrogen receptor, GPR30, in epithelial ovarian carcinoma andits correlation with MMP-9," ActaPhysiologicaSinica2010; 62(6): 524-528.

[35] Jala V. R., Radde B. N., Haribabu B., and Klinge C. M., "Enhanced expression of Gprotein coupled estrogen receptor (GPER/GPR30) in lung cancer," BMC Cancer. 12, pp. 624, (2012).

[36] Filardo E. J., Graeber C. T., Quinn J. A. et al., "Distribution of GPR30, a seven membranespanning estrogen receptor, in primary breast cancer and its association with clinicopathologic determinants of tumor progression," Clinical Cancer Research. 12(21), pp.6359-6366, (2006).

[37] Visciano C., Liotti F., Prevete N., Cali G., Franco R., Collina F., de Paulis A., Marone G., Santoro M., Melillo R.M., Mast cells induce epithelial-to-mesenchymal transition and stem cell features in human thyroid cancer cells through an IL-8-Akt- Slug pathway, Oncogene. 34, pp.5175-5186, (2015).

[38] Wang J., Hu W., Wang K., Yu J., Luo B., Luo G., Wang W., Wang H., Li J., Wen J.,Repertaxin, an inhibitor of the chemokine receptors CXCR1 and CXCR2, inhibits malignant behavior of human gastric cancer MKN45 cells in vitro and in vivo and enhances efficacy of 5-fluorouracil, Int. J. Oncol. 48, pp.1341-1352,(2016).

[39] Liotti F., De Pizzol M., Allegretti M., Prevete N., Melillo R.M., Multiple anti-tumor effects of Reparixin on thyroid cancer, Oncotarget. 8(22), pp. 35946-35961, (2017).

[40] Ensinger C., Prommegger R., Kendler D., Gabriel M., Spizzo G., Mikuz G. andKremser R., Her2/neu expression in poorlydifferentiated and anaplastic thyroid carcinomas,Anticancer Research.23, pp.23492353, (2003).

[41] Mondi M.M., Rich R., Ituarte P., Wong M., Bergman S., Clark O.H. and Perrier N.D., HER2 expression in thyroid tumors,American Surgeon.69, pp. 1100-1103, (2003).

[42] Wiseman S.M., Griffith O.L., Melck A., Masoudi H., Gown A., Nabi I.R. and Jones S.J., Evaluation of type 1 growth factor receptor family expression in benign and malignant thyroid lesions, American Journal of Surgery. 195, pp. 667-673, (2008)

[43] Mdah W.,Mzalbat R., Gilbey P., Stein M.,Sharabi A.,Zidan J., Lack of HER-2 gene amplification and association with pathological and clinical characteristics of differentiated thyroid cancer, Mol. Clin. Oncol.2, pp.11071110, (2014).

[44] Gill M.K., Manjari M., Jain K., et al., Expression of Her-2/neu in colon carcinoma and its correlation with the histological grades 
Analysis of GPER1, CXCR1 and HER-2 Immuno Expression in Follicular Thyroid Lesions and their Possible Role as Diagnostic Markers

and the lymph nodes status, JCDR. 5, pp.15641568, (2011).

[45] Blok E.J., Kuppen P.J.K., Leeuwen J.E.M. and Sier C.F.M., Cytoplasmic Over expression of HER2: a Key Factor in Colorectal Cancer. Clinical Medicine Insights, Oncology. 7, pp. 41-51(2013).

[46] Pavlakis K., Kountourakis P., Stathopoulos E., et al., Her-2 protein expression, cellular localization, and gene amplification in colorectal carcinoma, Appl.Immunohistochem. Mol.Morphol. 15(4), pp.441-5, (2007).
[47] Caria P.,Cantara S., Frau D.V.,Pacini F., Vanni R., Dettori T., Genetic Heterogeneity of HER2 Amplification and Telomere Shortening in Papillary Thyroid Carcinoma, Int. J. Mol. Sci. 17, pp.1759,(2016).

[48] Sugg S.L.,Ezzat S., Zheng L., Rosen I.B., Freeman J.L., Asa S.L., Cytoplasmic staining of erbB-2 but not mRNA levels correlates with differentiation in human thyroid neoplasia,Clin. Endocrinol. 49, pp. 629-637, (1998).

Citation: Nisreen A.A. Osman. Analysis of GPER1, CXCR1 and HER-2 Immuno Expression in Follicular Thyroid Lesions and their Possible Role as Diagnostic Markers. ARC Journal of Cancer Science 2017; 3(2):21-30. DOI: http://dx.doi.org/10.20431/2455-6009.0302004

Copyright: (C) 2017 Authors. This is an open-access article distributed under the terms of the Creative Commons Attribution License, which permits unrestricted use, distribution, and reproduction in any medium, provided the original author and source are credited. 